\title{
Reciprocity: A Fragile Equilibrium
}

\author{
Pauline Westerman
}

'For justice exists only between men whose mutual relations are governed by law; and law exists for men between whom there is injustice.'

Aristotle, Nic. Eth. V, 6

\section{Introduction}

The relation between law and reciprocity seems a fairly evident one. The law offers many examples of rules that admonish us to maintain and, if upset, to restore a certain balance between two parties. This is most evident in private law. If A harms B, A should compensate B for his losses. If A has paid B, B should return the benefit by executing the task for which he was paid. But it also pertains to criminal law. If $\mathrm{A}$ has done some wrong, he should be wronged as well. The image of the scales of justice naturally presents itself here. If one of the scales is lowered (by suffering harm) the other scale should be lowered as well in order to restore the balance. That is why it is stressed that the corrective measure should be in proportion to the original act. Only then is the original act truly reciprocated; only then, the balance restored.

The fact that the content of many legal rules revolves around restoring the balance between two parties has led to the assumption that reciprocity is the normative basis of law. This view can be understood in two different senses. It can be interpreted as the proposition that the origins of law and the transformation of benefits and burdens into rights and obligations can only be explained as the result of reciprocal exchange between two parties. In such an explanatory account, the exchange need not be just or fair. This reading, although interesting in itself, will not be addressed here. The second reading is that law can only be justified if it fulfils the requirements of reciprocity. In this latter claim, reciprocity is usually seen as a fair exchange between two roughly equal parties.

In this article I will deal with the latter claim, criticizing the highly idealized and normative notions of reciprocity that currently figure in justificatory theories and arguing that not only in explanatory theories but also in justificatory attempts we should make use of the insights of sociological and anthropological theories of exchange. According to these theories the dynamics of reciprocal exchange reveal that if there is any equality between partners it can easily be destroyed, and that the balance between partners is extremely fragile. Continuous maintenance is required in order to create and maintain a level playing field. I will therefore conclude that reciprocity should not be presupposed as the normative underpinning of law, but rather that, inversely, law should be presupposed in order to turn reciprocity into a desirable ideal. 


\section{Figure 1}

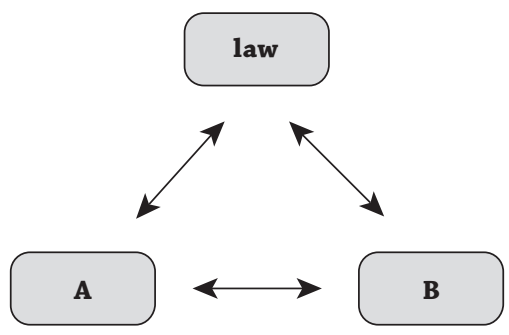

\section{From three to two}

In order to understand the appeals to reciprocity as a justificatory basis of law, it is important to realize that all such theories necessarily have to cast a triadic relation in the model of a dyadic one. Schematically, the relation of the law and its subjects can be pictured as a triadic one (see Figure 1 ).

This may not be self-evident. Usually, the set of rules pertaining to the relation between A and B are not seen as a 'third element.' However, the need for a third element immediately surfaces in those cases where something goes wrong. If $\mathrm{B}$ does not live up to the terms of the contract, the law, more properly speaking the judge, should intervene to redress the balance.

Nowadays, law's operation usually involves more than that. The lawgiver may want to do more than just see to it that contracts are maintained. He wants to add extra considerations, such as whether the contract is fair, whether it does not harm third parties, etc. So essentially, the attempt to ground the law in reciprocal relations between $\mathrm{A}$ and $\mathrm{B}$ implies that this activity is hidden from view. To ground law in reciprocity entails the attempt to recast a triadic relation into a dyadic one.

A good example of such a reduction can be found in the theory of John Rawls. For Rawls, justice and fairness should be understood in terms of reciprocal relations between free and equal persons who recognize 'one another as persons with similar interests and capacities. ${ }^{1}$ Rawls clearly and explicitly rejects the view, attributed to utilitarianism, that justice should be distributed by a superior lawgiver or administrator. It is only the mutual recognition of $A$ and $B$ as persons that can be the sound basis for justice.

1 John Rawls, 'Justice as Reciprocity,' in John Rawls, Collected Papers, ed. Samuel Freeman (Cambridge, MA: Harvard University Press, 1999), 190-224, at 213. 


\section{Figure 2}

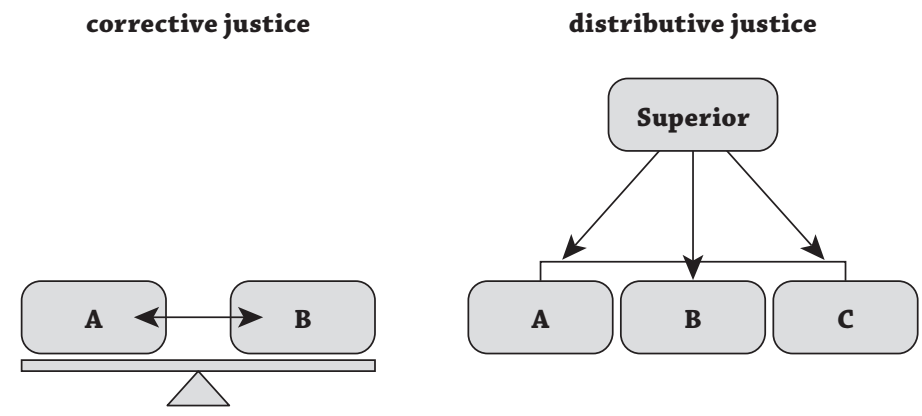

Rawls's view can be understood by means of the Aristotelian distinction between corrective justice and distributive justice (Figure 2 ). ${ }^{2}$

Corrective justice refers to the relation between two parties, and consists in the proportionate return for what has been given. If the original act is positive (a benefit conferred) the reciprocal act consists in returning the benefit; if the original act is negative (A wronged B), B is entitled to punish A in return.

Distributive justice, on the other hand, has to do with the way in which a superior distributes benefits and burdens among several recipients, $\mathrm{A}, \mathrm{B}$, and $\mathrm{C}$, like a king over his subjects or a father over his heirs. As is exemplified by the typical metaphor of the father who has to decide between the talented son $A$, the needs of handicapped son $\mathrm{B}$, and the lazy, luxuriously living son $\mathrm{C}$, the distributor has to decide on the set of criteria to be used in order to allocate the benefits or burdens. Should the allocation be guided by merit, need, or any other criterion? The choice of this criterion depends in turn on the purpose the distributor has in mind. ${ }^{3}$

For Rawls, distributive justice is no real justice but at best 'benevolence.' If there is some justice to be found in distributive justice, Rawls writes, it is a 'contingent result of a higher order administrative decision.' 4 This seems to be too harsh a judgment - the decision of the distributor may be a morally defensible one - but the decisive point for Rawls is that in a distributive model of justice, $A, B$, and $C$ do not relate to each other. They are just 'the many separate directions in which benefits and burdens may be assigned. ${ }^{5}$ The superior decides on the maximum

2 Aristotle, Nicomachean Ethics V, 4, <http://classics.mit.edu/Aristotle/nicomachaen.html〉, accessed August 2013. See also Eckhof who called these forms reciprocation and allocation respectively, Torstein Eckhoff, Justice: Its Deteminants in Social Interaction (Rotterdam: Rotterdam University Press, 1974), 3.

3 Rawls rejects distributive justice by identifying it with utilitarianism, but it seems to me that utilitarianism only provides a possible answer to this question.

4 Rawls, 'Justice as Reciprocity,' 216.

5 Rawls, 'Justice as Reciprocity,' 218. 
welfare; and the claims of $\mathrm{A}, \mathrm{B}$, and $\mathrm{C}$ with respect to each other are not taken into account. This form of justice 'is a kind of efficiency.' ${ }^{6}$ So, according to Rawls, law is only just law if it is mutually acknowledged as fair by free and equal persons. The overarching body of law itself owes its justification entirely to these horizontal relations.

As is well-known, Rawls's view is firmly rooted in the contract tradition of the seventeenth century, which emphasized the existence of certain primordial, natural rights as the sole basis for justice. Hugo Grotius, amongst others, derived the existence of an overarching body of law from the natural rights of $A$ and $B$ and equally confined his analysis to corrective justice. He did this by means of the notion of 'perfect rights.' A 'perfect right' is enforceable and legally binding. Grotius adds that perfect rights only play a role in corrective justice. ${ }^{7}$ Distributive justice deals with so-called 'imperfect rights' or 'aptitudes.' An aptitude is not legally binding, nor is it enforceable. It denotes merely 'that which is suitable or fitting.' Connected with distributive justice, Grotius writes, are 'those virtues which have as their purpose to do good to others, as generosity, compassion, and

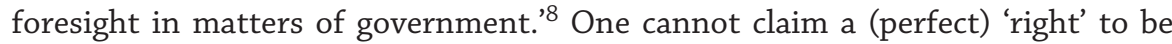
treated compassionately. One can only say that it would be suitable if a man is treated with compassion in a certain case. Because distributive justice is regarded as only dealing with imperfect, not with perfect rights, distributive justice is purged from the realm of law.

Here we see the forerunner of Rawls's remark that justice, in distributive justice, is no more than 'benevolence.' The rights and duties that spring from the reciprocal relations between self-interested, rational, free, and equal persons, are conceived as the 'real stuff.' They form the basis of law.

\section{The autonomy of persons... and of law}

It is not my intention here to rehearse the long and familiar history of natural rights as the basis for governmental and legal authority and its claims to obedience. As is well-known, the notion of natural and perfect rights could successfully be used to confine the scope of governmental power. By emphasizing that human beings were endowed with natural and perfect rights it was claimed that they could and should not be seen as instruments in the hands of a legislator, even a benevolent one.

But not only human beings were seen as autonomous and independent persons, that could but should not be instrumentalized. The reconstruction of a triadic relation into a dyadic one also served another aim. The emphasis on corrective

6 Rawls, 'Justice as Reciprocity,' 215.

7 See my The Disintegration of Natural Law Theory: From Aquinas to Finnis (Leiden: Brill, 1998), 174.

8 Hugo Grotius, 'De Jure Belli ac Pacis Libri Tres,' ed. James Brown Scott, transl. F.W.Kelsey, in The Classics of International Law (Oxford, Clarendon Press, 1925 [1625]), I,I,VIII,1. 
justice as the proper basis of law could also serve to advocate and confirm the autonomy of law.

In a model of corrective justice, the working of law is simply reduced to the operation of attaching consequences to conditions. The original act of party $\mathrm{A}$ is a condition for the counteract of $\mathrm{B}$. If $\mathrm{A}$ has wronged $\mathrm{B}$, then $\mathrm{B}$ should be paid compensation. The judge, not the legislator, is here the paradigmatic figure. Judicial decision-making is about linking conditions to consequences and making sure that these consequences are effectuated. Legal consequences are to a large extent guided, if not dictated, by the actions of A towards B. No political insight, no political preferences are needed for such operations. Whereas the distributor in distributive law should have a purpose in mind which informs his criteria for distributing burdens and benefits to the recipients, corrective justice seems to proceed as it were 'by itself.' The past behaviour of A is in itself (sufficient) reason for treating $\mathrm{B}$. The principle of reciprocity guides law's operation. ${ }^{9}$

The attempt to smuggle away the legislator and to pretend that rights, duties and legal procedures flow automatically from reciprocal relations between free and equal parties can therefore also be understood as an attempt to de-politicize legal relations. It conceals that even those areas of private law that closely resemble the corrective justice ideal are affected by legislators, past and present, who decide on the resources and possibilities allocated to A and B. This allocation is hidden from view in a model of corrective justice. Corrective justice is about restoring the balance, not about striking the balance. How burdens and benefits should be allocated in the first place is determined by the distributor in the distributive model and involves political decision-making, yet this is cut out from the sphere of law proper.

In Grotius' case, this attempt to de-politicize law was to a certain extent a necessity. The only way to claim room for an independent and autonomous body of law in war-torn seventeenth-century Europe was to deny its political character. But this practice stretches into the present day, where we see that not only moral philosophers but also lawyers happily make use of the notion of corrective justice in order to substantiate their claim that law is autonomous and independent of politics. Weinrib's defence of a coherent and autonomous body of private law is a case in point. ${ }^{10}$

The de-politicization of law may be an honourable enterprise but has its price. If legal relations are not seen as the outcome of political decisions, they are also immune to political criticism. The ideal of reciprocity, in its limited capacity of restoring the balance, is in itself unable to criticize the distributor's decisions. That means that it is of very little use as a critical concept in the contemporary

9 Eckhoff, Justice, convincingly links the two forms of justice to Summers's distinction between rightness-reasons and goal-reasons. See Robert S. Summers, 'Two Types of Substantive Reasons: The Core of a Theory of Common-Law Justification,' Cornell Law Rev. 63-5 (June 1978): 707-88.

10 Ernest Joseph Weinrib, The Idea of Private Law (Cambridge, MA: Harvard University Press, 1995), ch. 3. 
legal landscape. The emergence of the administrative state, which almost exclusively deals with the distribution of burdens and benefits, the enormous amount of legislation which is entirely policy-driven, and the fact that legal arrangements are mainly seen as instruments in order to achieve certain policy-goals, render obsolete this view of law as merely corrective justice.

Of course, one may object that although the practice of law can no longer be described in terms of corrective justice alone, the ideal of reciprocity and of corrective justice as the supreme model of law does not lose significance. But if this objection holds true, it is a rather impotent ideal. There are very few legal arrangements that fit the picture, and even those that do seem to fit - like tort law - are increasingly guided by 'higher order administrative decisions.' To confine oneself to the model of corrective justice alone is therefore an unhelpful strategy for those who want to make an informed judgement of the moral qualities of legal arrangements. If we want to develop conceptual tools that enable us to say whether some laws are just or not, or which kind of rules are morally better than other rules, we should make room for the fact that the law does not flow by itself from the principle of reciprocity but rather that it is to a large extent imposed by the legislator - or more precisely: by the many regulators who nowadays crowd the legal landscape - and who are all actively engaged in the distribution of benefits and burdens between $A, B$, and $C$.

\section{Idealized reciprocity}

The underlying assumption of those who advocate the autonomy of law is that autonomous law, as it is untainted by the political whim of the day, is also just law. Motto's like 'giving everyone his due,' and 'like cases should be treated alike' testify to the desire to attribute a kind of 'intrinsic' justice to the way conditions are linked to consequences. But as Kelsen already noted, ${ }^{11}$ such propositions do not inform us about what counts as 'due' and what counts as 'alike.' There may be tensions between autonomous (non-instrumentalized) law and just law. Autonomous law, proceeding from conditions to consequences, takes the status quo, the initial situation-to-be-restored for granted. And since this initial situation is not necessarily just, the restoration need not be a just operation. So for those who, like Grotius and Rawls, do not want to deal with the triadic model of distributive justice, it is important to pretend that the initial balance between $A$ and $B$ is a fair one. The presumption of free and equal partners is crucial in order to reconcile justice with autonomy, or, to put it differently, to develop a concept of justice independent from politics.

This idealized version of human nature has always been problematic. Seventeenth-century natural law thinkers struggled to distinguish so-called 'accidental' traits of human nature from 'essential' traits. Only 'essential' features could serve

11 Hans Kelsen, 'What is Justice?,' in H. Kelsen, Essays in Legal and Moral Philosophy, ed. Ota Weinberger, (Dordrecht: Reidel, 1973 [1953]), 1-26. 
as 'axioms' from which to deduce the precepts of natural law. ${ }^{12}$ In order to derive a moral touchstone from human nature, human nature had to be modified and presented in its best light. In fact, in such a favourable light that Mill could exclaim that if men were so perfect, why would natural law be needed in the first place: 'If the natural course of things were perfectly right and satisfactory, to act at all would be a gratuitous meddling, which as it could not make things better, must make them worse.'13

The same applies to the fiction of reciprocity between free and equal partners. In order to arrive at the formulation of principles of justice and fairness, Rawls is careful to distinguish the features of deliberating partners (rational, endowed with a sense of justice, veiled with ignorance) from human beings as they 'really are.' This also affects his concept of reciprocity. It is the reciprocal and mutual recognition of one another as rational persons which is at the basis of the duty of 'fair play,' even if this demands at times acting contrary to one's self-interest. Rawls compares this mutual recognition to empathy for another's suffering. ${ }^{14}$

Reciprocity is here no longer a feature of a relation in which $\mathrm{A}$ has rights and duties towards B and vice versa, but is simply identified with the possibility of communication. This view has given rise to an extensive literature in which reciprocity is understood as 'taking the point of view of the other.' Reciprocity is then not only seen as the basis of law, but of communication and deliberation in general. ${ }^{15}$ I think that the concept of reciprocity is here needlessly reduced to 'being and talking together.' This may be a good description of what philosophers mostly do, but has little specific to say about how rights and duties should be distributed.

Sometimes, reciprocity is still linked with exchange relations, but is depicted in a romantic way in order to distinguish it sharply from economic exchange. Reciprocity is then claimed to be the basis of all social intercourse, 'generating social cohesion and solidarity.' The free giving without stipulating the conditions for returns is heralded as a sign of trust, without which society would not be possible. Reciprocity is thus distinguished from mere 'mutuality,' which expresses the exchange relations on the market, i.e., temporary exchanges between strangers, calculated and inspired by distrust. ${ }^{16}$

Such idealized versions of reciprocity can neither explain nor justify law. In fact, Mill's criticism would be even more appropriate here than in the case of the seventeenth-century natural law thinkers. These authors not only talked about 
empathy and recognition of the other but also about the reciprocity of rights and duties. Moreover, they coupled their analysis of human nature with the notion of a state of war. The principle of reciprocity may result in mutual benefit but may also end in a vendetta, reciprocating evil for evil. ${ }^{17}$ Hobbes not only used the notion of 'state of war' to describe a situation of real war, but also the situation of 'precarious peace' which was, in the absence of common authority, maintained by 'reciprocal fear.' ${ }^{18}$ Reciprocity, so it is acknowledged by all natural lawyers, should be regulated by an appeal to a common authority or judge who should see to it that the give and take of burdens and benefits will not run out of hand. Their justification of governmental power was not based on a romantic kind of reciprocity as solidarity or mutual understanding but on the undesirability of unregulated reciprocity in the exchange of rights and duties.

\section{Reciprocity: cohesion and differentiation of power}

Modern justifications of political power hardly make use of notions such as the state of war or precarious peace. Probably due to the emphasis on reciprocity as mutual understanding and deliberation, reciprocity as a form of exchange of burdens and benefits has practically disappeared from view. This may be one of the reasons why hardly any use was made of the extensive sociological and anthropological literature developed in the second half of the previous century on exchange relations and reciprocity. ${ }^{19}$

I think that this is a missed opportunity. This literature has a lot to teach us about the dynamic of reciprocal relations. Anthropological studies of societies which are exclusively based on dyadic reciprocal exchange relations tell us what

17 So-called negative reciprocity, mentioned by both Pessers and Komter in this issue, but left out from consideration by Pessers.

18 Norberto Bobbio, Thomas Hobbes and the Natural Law Tradition (Chicago: University of Chicago Press, 1993), 43.

19 A small selection: Bronisław Malinowski, 'The Principle of Give and Take,' in Crime and Custom in Savage Society (London: Routledge \& Kegan Paul, 1970 [1926]), 39-45; Bronisław Malinowski, Argonauts of the Western Pacific: An Account of Native Enterprise and Adventure in the Archipelagoes of Melanesian New Guinea (London: Routledge \& Kegan Paul, 1983 [1922]); Marcel Mauss, The Gift: Forms and Functions of Exchange in Archaic Societies, transl. Ian Gunnison, introd. E. EvansPritchard (London: Cohen \& West, 1966); Claude Lévi-Strauss, 'The Principle of Reciprocity' ('Le principe de réciprocité,') in Les Structures Elémentaires de la Parenté, (Paris: Presses Universitaires de France, 1949), ch. 5; Rose L. Coser \& Grace Frazer, 'xxx,' transl. and abridg. in eds. L.A. Coser \& B. Rosenberg, Sociological Theory: A Book of Readings (New York: MacMillan, 1957), 84-94; Ruth Benedict, Patterns of Culture, introd. Franz Boas, pref. Margaret Mead (London: Routledge \& Kegan Paul, 1960 [1946]), ch. 6; Peter M. Blau, Exchange and Power in Social Life, With a New Introduction by the Author (New Brunswick and Oxford: Transaction Publishers, 1989 [1964]); Alvin W. Gouldner, 'The Norm of Reciprocity: A Preliminary Statement,' American Sociological Review 25-2 (April 1960), 161-78. A very valuable collection of interesting contributions on exchange theory is to be found in Aafke E. Komter (ed.), The Gift: An Interdisciplinary Perspective (Amsterdam: Amsterdam University Press, 1996.) 
happens if there is no third element, no law to regulate these relations. ${ }^{20}$ Sociological studies illustrate the fact that these findings can be generalized to all sorts of exchange relations, within and without the modern world. ${ }^{21} \mathrm{I}$ will confine myself here to enumerating a couple of key characteristics of reciprocal exchange.

The first point that is universally acknowledged is that if A gives to B, A imposes an obligation to B to reciprocate and to return the gift. ${ }^{22}$ Lévi-Strauss clarifies this by means of the French example of people dining in cheap restaurants, where in his time it was the custom to share wine. After the first offering of wine, LéviStrauss notes, the situation is no longer a neutral one: one cannot remain strangers. It is now friend or foe: if one returns a glass of wine, one is absolved from the obligation and the social bond is confirmed. Not returning is either an sign of hostility or of unreliability. ${ }^{23}$

The second feature is that the dynamics of give and take has both a strategic and a moral aspect. If I receive a present I feel obliged to return the favour, not only because of the fact that this is a 'fair' reaction to the benefit I received, but at the same time in order to prove myself as an equal and creditable person who can be trusted as a reliable (future) partner. So the return-gift is both 'retributive' (past regarding) and 'instrumental' (future-oriented) at the same time. The gift I received is the condition for my return-gift, but since my return-gift will be in turn a condition for the other's future conduct towards me, it is instrumental at the same time. As a kind of antidote to reciprocity romanticism, Blau quotes Rochefoucauld's famous maxim: 'We pay our debts, not because it is right that we should discharge them, but in order more easily to borrow again.' But it may be more accurate to emphasize the double sidedness of reciprocity which has both a 'moral' and a calculative aspect at the same time. In this sense I don't see why we should make a preliminary distinction between gift and exchange. If we reserve the word 'gift' for that which is free, generous, and spontaneous, and 'exchange' for that which is given with an eye for future benefit, we may fall in the same trap as those who differentiate 'reciprocity' from 'mutuality' and end up by presupposing what should be explained. ${ }^{24}$

20 See, e.g., Marshall D. Sahlins, 'Poor Man, Rich Man, Big-Man, Chief: Political Types in Melanesia and Polynesia,' Comparative Studies in Society and History 5-3 (1963): 285-303.

21 See for a completely different context, e.g., William Foote Whyte, Street Corner Society: The Social Structure of an Italian Slum, third ed. (Chicago: University of Chicago Press, 1981 [1943]).

22 See Georg Simmel, 'Faithfulness and gratitude,' from The sociology of Georg Simmel, trans. and ed. K.H. Wolff (New York: The Free Press, 1950 [1908]), 379-95, in Komter, Gift; Blau, Exchange and Power in Social Life.

23 Lévi-Strauss, Principle of Reciprocity. I will not deal here with the highly interesting question whether a norm of reciprocity should be assumed to exist prior to exchange-relations (cf. Gouldner) or whether this norm establishes itself as a result of the exchange (cf. Blau).

24 Cf. Eckhoff, Justice, 12, who notes that the current distinctions between strategic and normative actions is misleading. This not only applies to exchange relations but also to law in general. The common identification of law with (past regarding) reactions to previous acts is probably inspired by the fact that legal reasoning often proceeds from conditions to consequences, rather than from aims to means. But that does not imply that legal norms are necessarily 'non-instrumental.' 
The third feature of exchange relations is related to the first two. Because giving is a way to create social ties, the giver usually gives to those people with whom the relation is not (yet) stabilized. That nowadays women give more to others, and the poor more to the rich than the other way around, ${ }^{25}$ testifies to the fact that the gift is supposed to create what was not there. Since the social bonds are only strengthened if reciprocated by a return gift, people will not give to those who are unable to return the gift. This means that one enters into exchange relations with either equals or superiors. The well-known exchange relations on the Trobriand Island as described by Malinowski are with (equal) strangers, not with relatives and dependants. ${ }^{26}$ Sacrifices to the gods can also be understood as an attempt to pacify them and to oblige them into returning the favours.

The fourth feature is that although reciprocal exchange presupposes equality, it has an inherent tendency towards inequality. This mechanism is described by Blau $^{27}$ and vividly illustrated by Sahlin's description of exchange relations in Melanesia. ${ }^{28}$ If $\mathrm{A}$ gives to $\mathrm{B}, \mathrm{B}$ is obliged to reciprocate at some undefined later moment. If he returns more than the original gift (with 'moka' or 'interest') B proves to be an attractive partner in the future and also to others ('big man'). If he returns the gift but fails to deliver this extra 'interest,' he will at best remain on equal footing with the original giver. But if he fails to reciprocate at all or returns less than what was given, his reputation will be tarnished. He has discredited himself ('rubbish man') and no one will want to deal with him anymore.

The fifth feature is the consequence of the third: inequality will lead to differentiation of power. Those who are unable to reciprocate are still under an obligation to do so; an obligation that can only be fulfilled by offering something else, for instance one's labour or services. ${ }^{29}$ This phenomenon, described and analyzed by Blau, is again nicely illustrated by the Melanesian example. The only option available to the 'rubbish man' is to become a follower. For the big man it is attractive to have as many followers as possible. The followers, the extended household or in-group, are, by means of their labour, literally producing gifts and form the basis of his generosity, i.e., his reputation as a creditable man. ${ }^{30}$

Differentiation of power therefore often - although not necessarily - goes hand in hand with exploitation. The more followers the big man has, the more gifts he can give, and the more success he will have in the competition with the equals of the outside world. This does not imply that the big man should not from time to time share his gains with the in-group if he wants to be sure of their cooperation; but he should not be too generous towards his dependants, at the risk of no lon-

See Aafke E. Komter, 'Women, Gifts and Power,' 119-31 and 'The Social and Psychological Significance of Gift Giving in the Netherlands,' 107-18, both in Komter, Gift.

26 Sometimes the boundary between giving and acting hostile cannot clearly be drawn; as in the case of the potlach, described by Benedict, Patterns of Culture.

27 Blau, Exchange and Power in Social Life, 25ff.

28 See Sahlin, 'Poor Man, Rich Man, Big-Man, Chief.'

29 Blau, Exchange and Power in Social Life, esp. ch. 5.

30 See Sahlin, 'Poor Man, Rich Man, Big-Man, Chief.' 


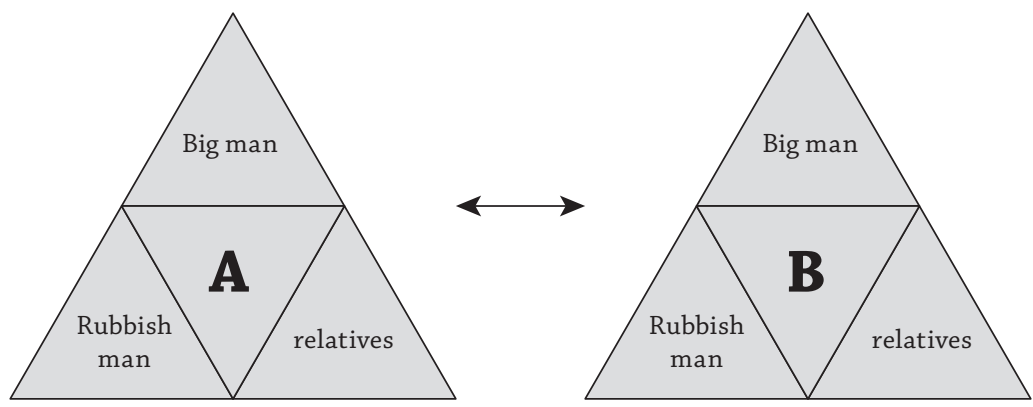

ger being able to reciprocate the gifts of outsiders and becoming a follower himself, as a result of which the whole household will be jeopardized. ${ }^{31}$ His position is comparable to that of the modern $\mathrm{CEO}$ who tries to cut wages in order to compete better.

This dynamic seems to apply to all kinds of exchange relations, no matter the objects of exchange or the motives of the partners. Truly reciprocal relations are only possible between partners who are able to reciprocate one another's benefits. This means that reciprocity is only possible between people who are - indeed equals or 'similarly situated,' as Rawls notes. Those who are unable to reciprocate - the handicapped, children - are excluded from this group of peers and may at best turn into dependent persons or followers. Blau notes that reciprocity, by creating social ties and by constituting the peer-group of creditable others, is at the same time responsible for creating differences in power. Those who are able to offer what is scarce or what is most needed or valued will soon gain the upper hand; they impose obligations on others and will feel entitled to their obedience in case they fail to reciprocate.

It seems then that the picture that arises from these examples is more complex than the picture of free and equal individuals (Figure 3).

The mutual relationship between A and B may be a fair one of give and take and solidarity, but there are always groups that have fallen out of this community of equals, and who are subordinated to $\mathrm{A}$ and $\mathrm{B}$ or even excluded entirely.

\section{A fragile equilibrium}

These theories, as briefly expounded here, are not only presented as a sobering antidote to the idealized picture of reciprocity that figures in moral theory. Exchange theory does not necessarily start from the assumption that individuals 
are egoistic or self-regarding. Nor is it my intention to stress the selfish motives for engaging in an exchange relation. There may be many motives at stake and they can be so hard to unravel that I think that the attempt to differentiate forms of exchange on the basis of motives ${ }^{32}$ is misleading and at best presupposes what should be explained.

Nor do I want to confine myself to a specific (materialistic) account of social exchange. The objects of exchange do not matter much. Rather, the entire mechanism hinges on reputation. Someone's reputation is formed by the opinions of others on the benefits that can be expected. These benefits do not necessarily consist in material goods but may also consist in advice, attention or praise. Since, in turn, the value of these immaterial goods is determined, among other things, by the relative positions of those who offer them (the attention of superiors is scarcer and more valuable than that of inferiors) power-inequalities are further reinforced. Those who can only offer a benefit that is in abundant supply, or which is not badly needed or less valued, will soon lag behind (or will start a new form of competition with peers at a lower echelon). ${ }^{33}$

The main lesson to be drawn here is, as far as I can see, that the equality that is so easily presumed to exist in reciprocal relations is extremely fragile. The equilibrium between partners, whatever the object of exchange or the motives of partners, can easily be distorted. In Blau's words: 'Reciprocity on one level, (...) entails imbalances on others. If persons are obligated to accede to another's wishes because he renders essential services to them for which they cannot otherwise compensate him, their compliance reciprocates for the unilateral services they obtain and in this sense restores balance, but it also creates an imbalance of power.' 34

It is in the fragility of the equilibrium, rather than in reciprocity as such, that justificatory reasons for law can be found. Although I certainly don't want to identify reciprocity with economic exchange only, because of the variety of objects, motives and values that can be at play, it is nevertheless tempting to compare the fragile equilibrium between partners to the free competition between economic partners. As any specialist on competition law knows, the 'freedom to compete' cannot exist and certainly cannot last without an enormous amount of regulation that promotes and maintains fair and free competition. Without such regulation, competitors quickly turn into cartels that would dominate the scene and restrict competition for others. It should be noted that the partners that form these cartels may entertain relations that are marked by a kind of reciprocity on fair and equal terms. But the equal and fair relations they entertain are achieved by excluding others from the market. Competition law therefore seeks to redress the

32 Alan P. Fiske, Structures of Social Life: The Four Elementary Forms of Human Relations (New York: The Free Press, 1991) quoted in Aafke Komter, 'Gifts and Social Relations: The Mechanisms of Reciprocity,' International Sociology 22 (2007): 93-107.

33 Blau, Exchange and Power in Social Life, ch. 5.

34 Blau, Exchange and Power in Social Life, 336. 
balance between the in-group and the out-group by destroying the mutual give and take within the cartel or in-group.

So although continuously new forms of unregulated reciprocity arise, the law should see to it that this reciprocity is not achieved by excluding others. The precarious balance between partners and above all the free and equal position of such partners should not be presupposed but should be the object of continuous concern and maintenance. Law should 'equalize what is unequal, ${ }^{35}$ it should see to it that the starting position between partners is a fair one, it should include those members of society who on the basis of reciprocity alone would be excluded because no benefits are expected from them, and it should put constraints on the amount and kind of exploitation that is inevitably brought about by unregulated exchange.

Reciprocity between free and equal citizens should therefore not be the startingpoint for the analysis of law, but, conversely, the law should be the starting-point for arriving at fair reciprocal relations.

\section{Conclusion}

In this article I criticized the assumption of reciprocity between free and equal partners as a useful starting-point for the justification of law. Although this idealized notion of reciprocity has fulfilled an important function in the history of political thought, in so far as it served to determine the limits of governmental interference, it systematically hides from view the amount of legal and political intervention needed to establish and to maintain reciprocal relations between citizens that are fair and equitable. In so far as the concept plays a role in the claim that law is autonomous, it neglects the fact that the balance which law helps to restore need not be a just one and that the starting positions of partners are to a large part to be determined by political and legal intervention. In so far as the concept plays a role in moral theory, its content is often watered down to the ability to take the viewpoint of others and to take seriously the reasons adduced by others.

Anthropological and sociological theories on exchange relations give a more realistic account of reciprocity. They teach us that an equilibrium is not something that can be preserved without any maintenance work. Both striking the balance and restoring the balance should therefore be regulated. The achievement of reciprocal relations that are fair calls, therefore, for a lot of hard work: political decision-making as well as good law-making. In order to establish a body of law which is well-equipped to do this successfully, sociological insights in the nature and mechanisms of reciprocity seem to be more appropriate and helpful than the fancies of moral philosophers. 